\title{
Foresight of the health system at the national level based on the Islamic-Iranian lifestyle and by identifying the goals and actions of key actors
}

\begin{abstract}
Background and Objective: Foresight of a new way of thinking that can challenge the originality of zero-one logic in the experimental sciences and modern medicine. This logic, by focusing on patient-health orientation and insisting on forecasting, leads health organizations and institutions to be passive in the face of future events. This study has been written with the aim of foresight with a backcasting approach and helping to build the future of the health system with a focus on health at the national level and based on the Islamic-Iranian lifestyle.

Materials and Methods: In this research, using the Laprospective school approach and using the process governing the software, the software analyzes the goals and actions of the actors as well as the relationship between the goals and the actors through in-depth interviews with 25 health system experts.

Results: Among the future goals of the country's health system, the goal of Organization and University Wisdom base as an infrastructure goal has the lowest net distance from other goals and among the actors of the Ministry of Health, Treatment and Medical Education, family physicians and non-governmental organizations has the highest Were important.

Conclusion: The current structure of the health system due to the patient-healthoriented approach is not responsible for dealing with the new generation of diseases due to lifestyle changes. Therefore, the Ministry of Health, Treatment and Medical Education needs to change the current paradigm governing the health system due to its duty to be the stewardship of the health system.

Keywords: Foresight, Health system, Islamic-Iranian lifestyle

Paper Type: Research Article.
\end{abstract}

Citation (Vancouver): Esmaili A, Izadi M, Azad E, Sanaee Nasab H. Foresight of the health system at the national level based on the Islamic-Iranian lifestyle and by identifying the goals and actions of key actors. Iran J Health Educ Health Promot. Winter 2021;8(4):378-389. [Persian]x

- Citation (APA): Esmaili A., Izadi M., Azad E., Sanaee Nasab H. Foresight of the health system at the national level based on the Islamic-Iranian lifestyle and by identifying the goals and actions of key actors. Iranian Journal of Health Education \& Health Promotion., 8(4),378-389. [Persian]

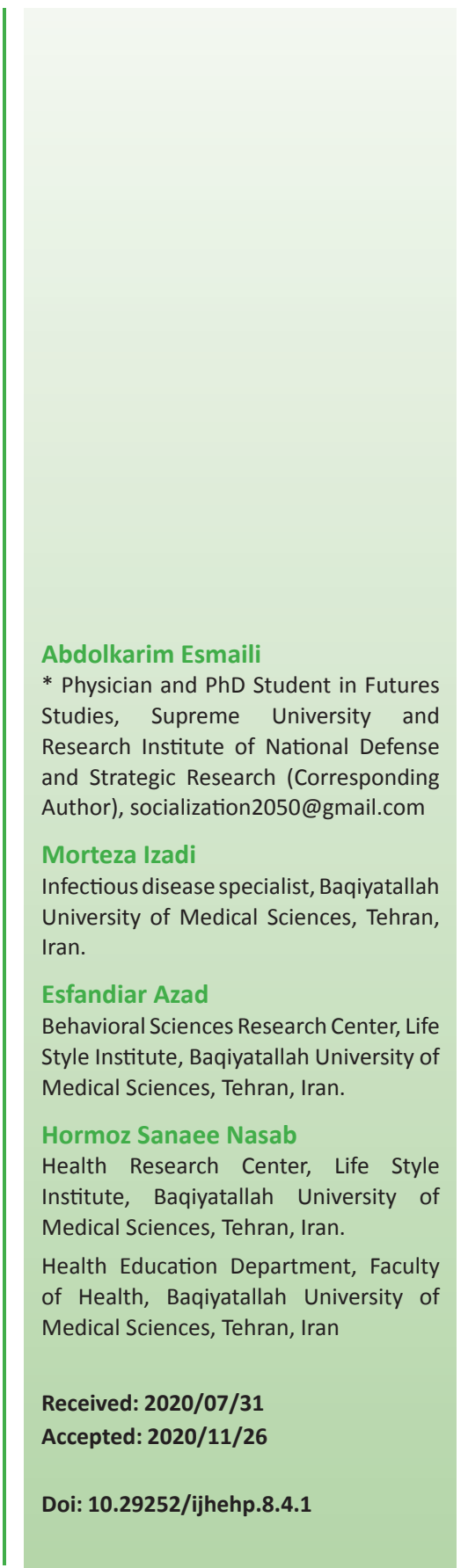




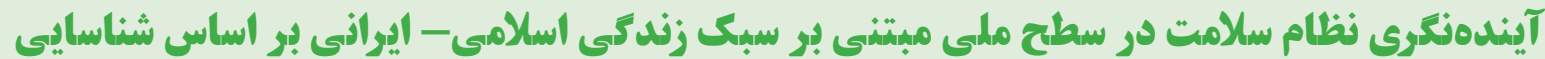

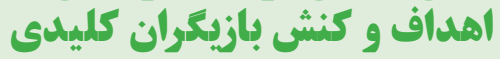

$$
\text { عبدالكريم اسمعيلى }
$$

* بزشك و دانشجوى دكترى آينديثروهى، دانشكاه

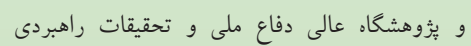
(نو يسنده مسئول) socialization2050@gmail.com

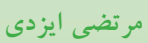
متخصص عفونى، دانشكاء علوم يُشكى بقيه الله، تهران،

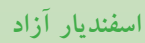

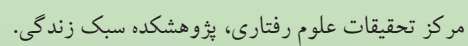

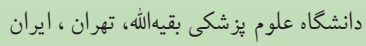

$$
\text { هر مز سنائى نسب }
$$

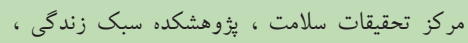

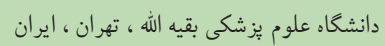

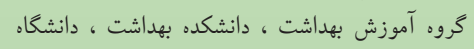

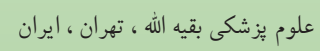
تاريخ د ريافت: 0 | | /

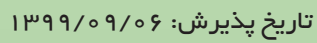

\section{0 ols}

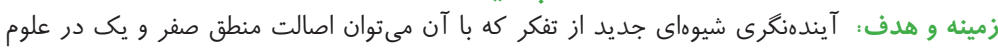

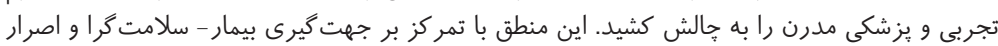

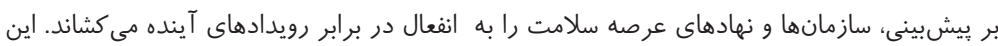

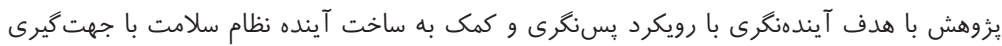

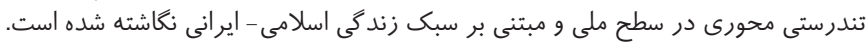

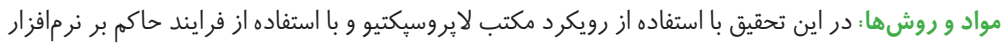

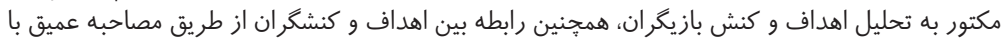

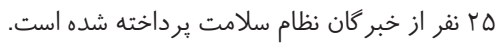

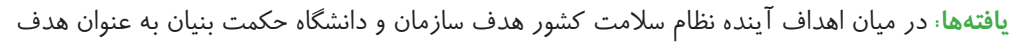

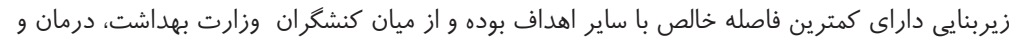

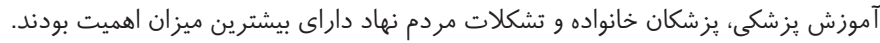

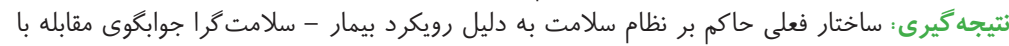

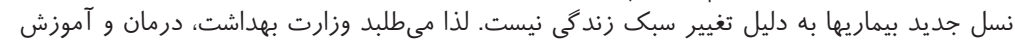

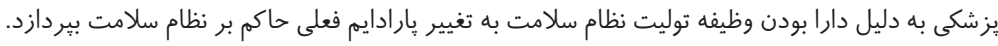

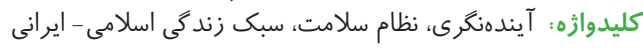
نوع مقاله : مطالعه يزوهشى.

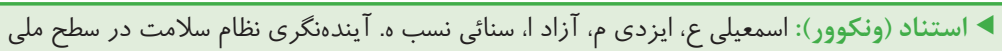

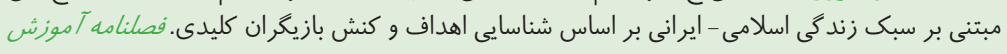

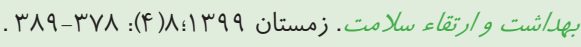

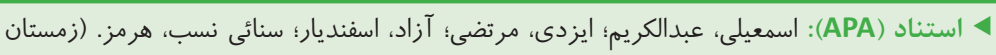

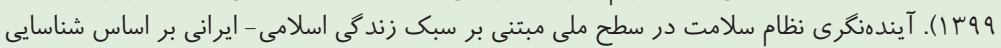

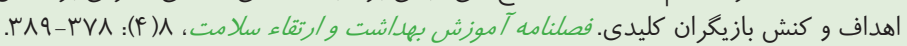


تحقيقات آيندهنكر انه نظام سلامت در بخشهاى مختلف و در قالبهاى كوناگونى مثل رسالهها انجام گرفته، لكن اكثر اين تحقيقات در درد

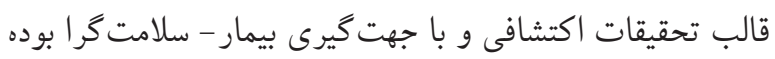

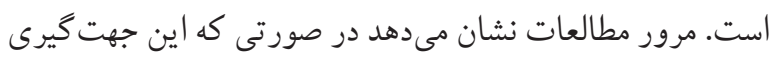

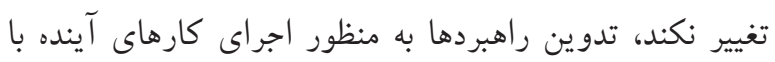
شكست روبرو مىشود. در عصر امروزى دو جهت گيرى در عرصه سلامت وجود دارد:

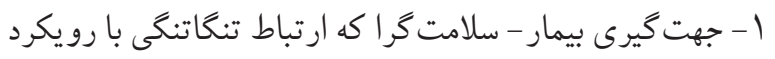

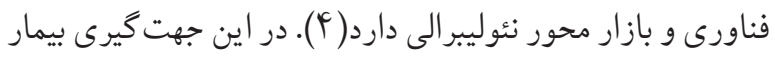

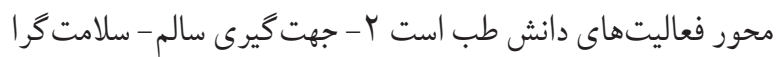
يا تندرستى محورى كه در آن محور فعاليتهاى دانش طب، انسان

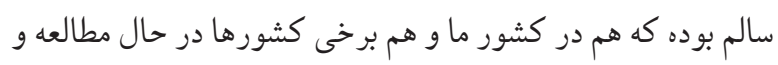

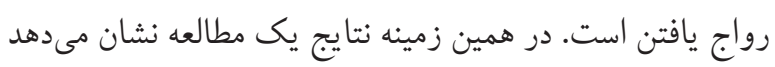

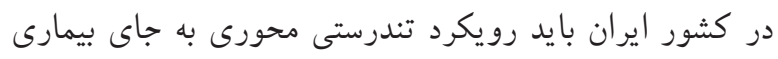

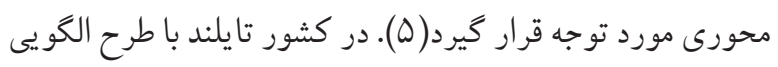

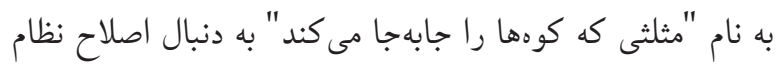

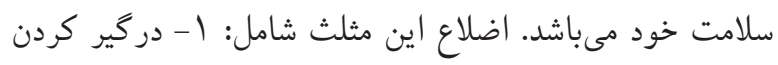

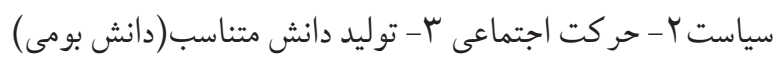
مىباشد. براى اجراى اين خواسته جهت گيرى منفعل بيمار محورى بايد به جهت كيرى تندرستى محورى تغيير يابد( (). سهيل عنايت الله

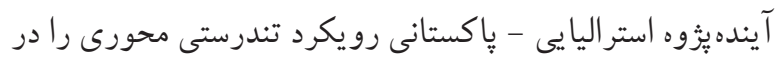

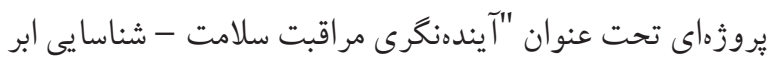

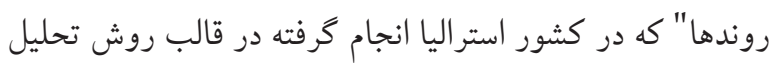

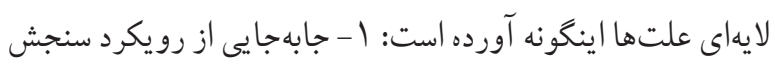

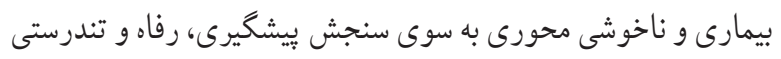

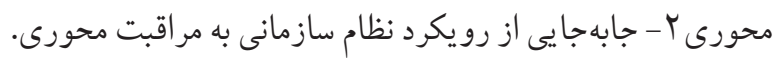

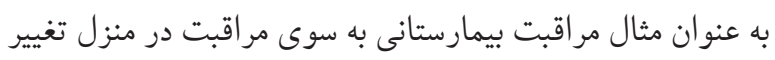

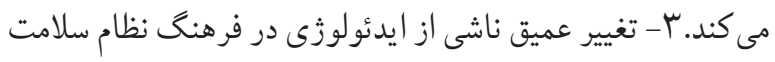

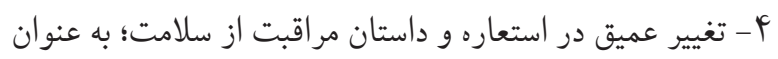

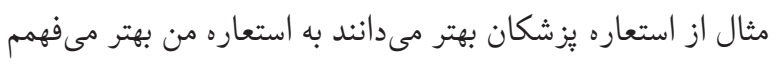

شكل گيرى نظام سلامت در جمهورى اسلامى ايران با شكل گيرى شبكه

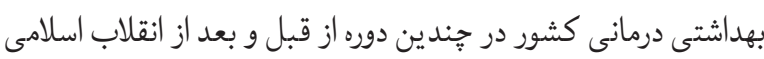
ايران صورت گرفته وقتى در كنفرانس آلماتا تندرستى براى همه تا

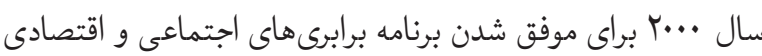

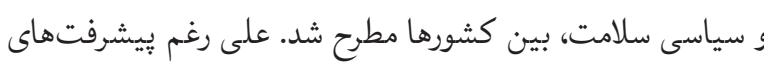

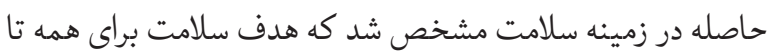

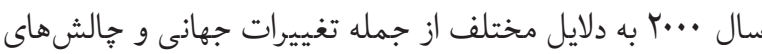
سياسى، اقتصادى، اجتماعى و فرهنكى مربوطه كه بر روى نظام سلامت

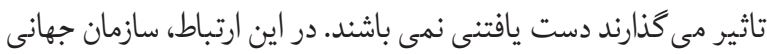

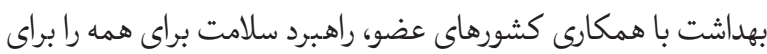

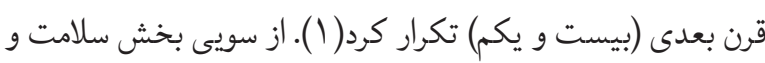

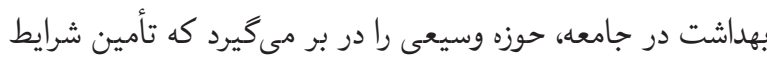
مناسب آن، عزم ملى مى طلبد و تامين آن از وظايف اصلى حكومته حستها و قوانين هر كشور كوياى جايگاه سلامت نزد حاكميت آن كشور

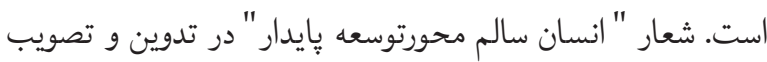

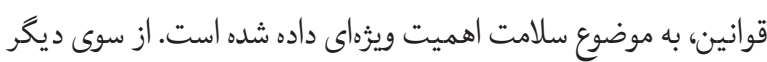
سند جشم انداز بيست ساله نظام جمهورى اسلامى به عنوان "ميثاق ملى" وجود دارد. در اين سند ويزّكى جامعه مطلوب تصور شده كه ئه بخش مهمى از آن برخوردارى از سلامت باكيفيت، زندكى مطلوب و و دونى

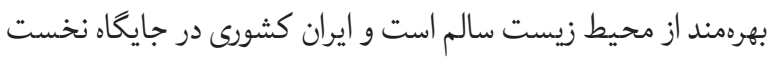

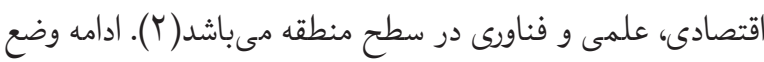

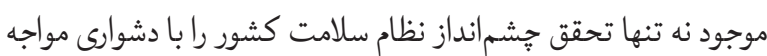
مى كند بلكه جوابخوى تقاضاى در حال افزايش مراقبت سلامت در آينده هـم نيست. تغييرات شتابان در حوزه هاى مختلف اجتماعى، سياسى، اقتصادى،

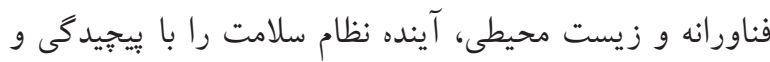

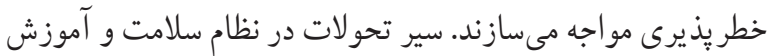

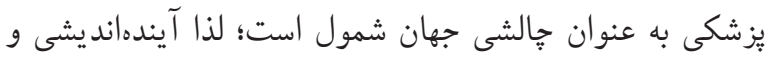

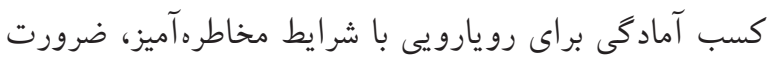

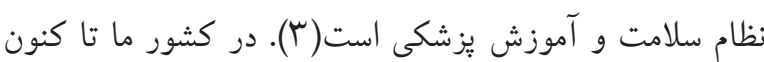


با در نظر كرفتن جهت كيرى تندرستى محورى كه مبتنى بر جهان بينى و سبك زندگى اسلامى - ايرانى در نظام سلامت كشور باشد اولاً

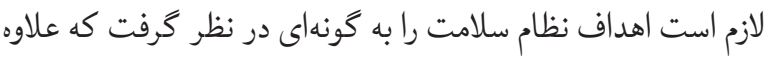
بر آرمان كرايى، واقعيتهاى ميدانى را نيز لحاظ كرد. ثانياً

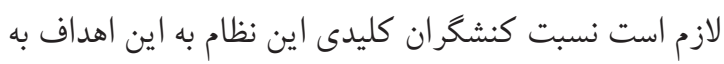
منظور فهم بهتر وضعيت حال نظام سلامت رادر كر كرد. بنابراين ما در اين تحقيق بادر نظر كرفتن اهداف نظام سلامت كار را از آينده شروع مى كنيم و در نهايت با سنجش نسبت كنشكران كليدى به

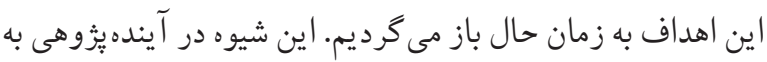

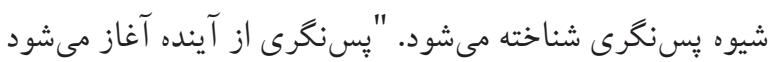

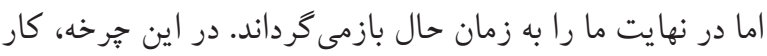
طراحى بهجاى شروع از وضعيت كنونى، از وضعيت آينده آغاز

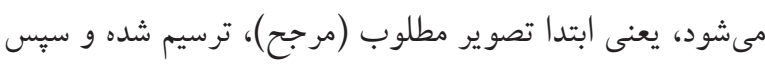

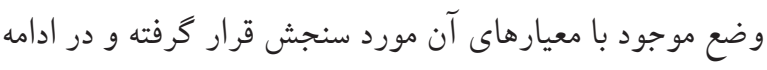
با توجه به شكاف بين اين دو، راهبردهاى تحولى، طراحى و اجرا

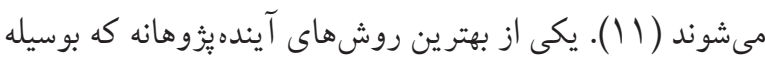

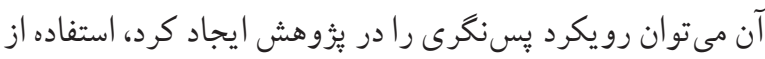

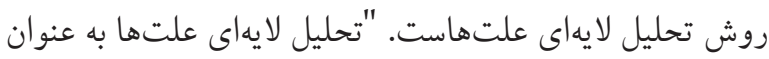

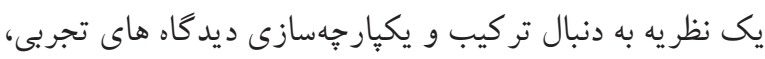

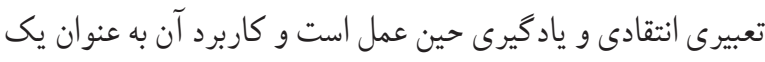

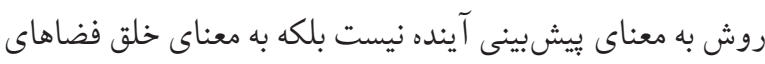

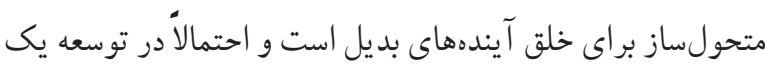

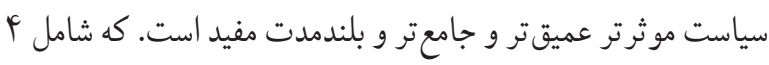
سطح ليتانى، اجتماعى، كفتمان / جهانبينى، اسطوره/ استعاره است.

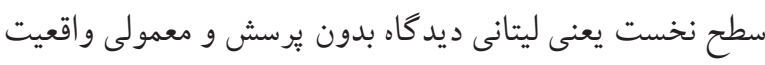
است. سطح دوم سطح علت هاى اجتماعى و دورنماى نظام ندند است.

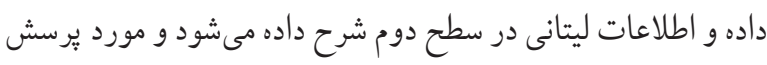

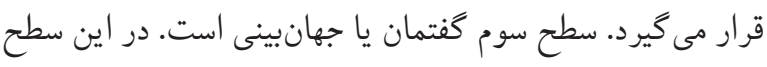
فرضهاى عميق تر، استدلالى، جهان بينى و ايدئولوزيك ناخو دآكاه مشخص مىشوند. در اين صورت مى توان به اكتشاف اين يرداخت

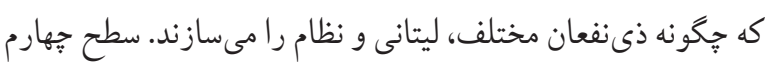

تغيير مى كند (V) . براى دستيابى به تندرستى محورى اصولى وجود

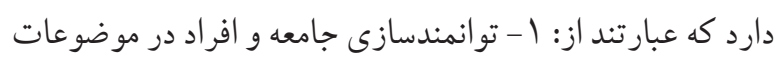
فردى، اجتماعى - اقتصادى و عوامل محيطى مد نظر باشد. Y- سياست

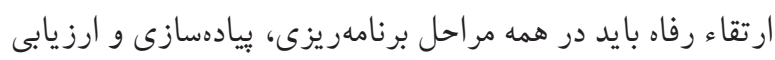

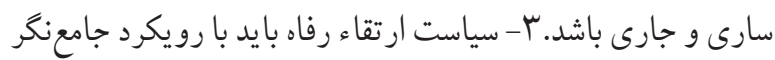

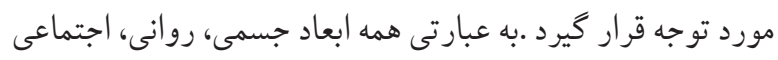

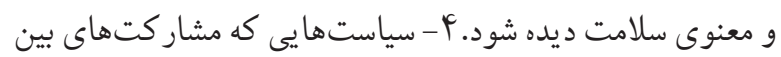
بخشى را توسعه مى دهد، مورد تاكيد قرار خيرد.ها - برابرى و وعدالت

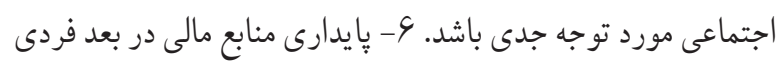

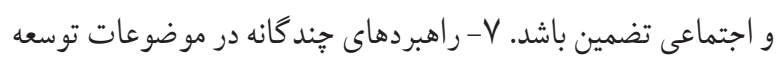
سياست، تغييرات سازمانى، توسعه جامعه، قانونكذارى، حمايت، آموزش و ارتباطات ديده شود(A). تندرستى محورى به به دو دليل تانيل

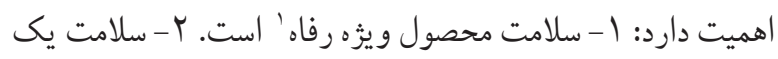

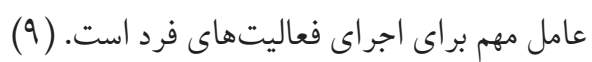

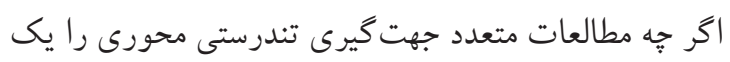
جهت كيرى صحيح در تامين آينده نظامهاى سلامت كشورها تندات مى داند لكن اين جهت كيرى جيزى جداى از جهانيبنى و سبك آنيل

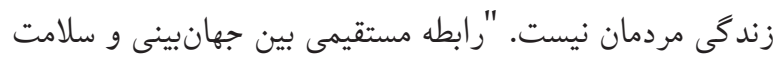

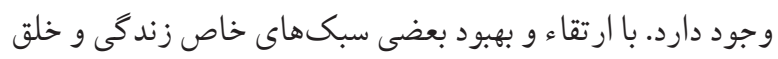

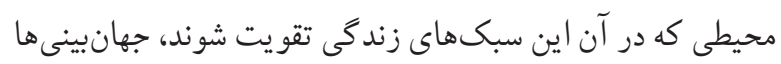
قادر به تعيين وضعيت سلامت افراد و جوامع هستند. اما همدينين جهانبينى ها ماتريسى راشكل ميددهند كه تلاشهايى جهت يافتين درمان بيمارىها و بهبود بهداشت و سلامتى در آن ديده مىشود در نتيجه يزشكى و طب فرزند بلاواسطه جهان بينى است: طب مدرن محصول جهان بينى تمدن غربى است. و نظامهاى بز شكى غيرغربى برنى - اسلامى، جينى آيوروديك - محصول تمدن ها و جهان بينى هاى

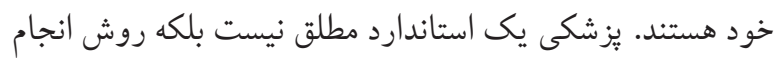
كارهاى يزشكى در يك جهانبينى است." (· ()

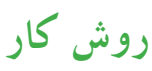


در مورد انتخاب نمونه "كاهى اوقات نوع تحقيق ايجاب مى كند

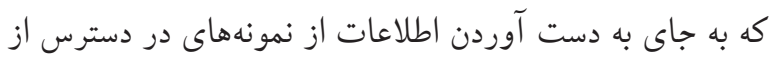
افراد يا كروههاى خاص استفاده نمايد. اين بدان دليل است كه

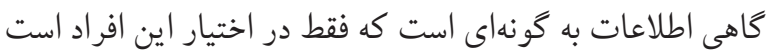
و يا اينكه ماهيت يُزوهش ايجاب مى كند كه نمونه با نظر محقق إنق

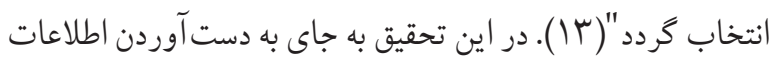

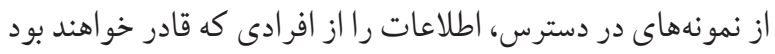

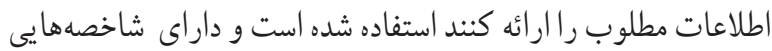
همجِون داشتن حداقل مدرك دكترى عمومى، دارا بودن تجربه

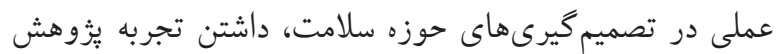
و تحقيق و برخوردار از تجربه مديريت مراكز علمى و تحقيقاتى،

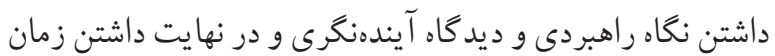
و تمايل جهت همكارى در يُزوهش بودهاند.

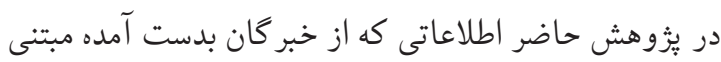

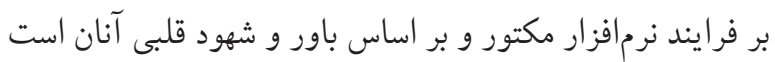
و لازم بود قبل از ير كردن دو ماتريس اين نرم افزار، خبر گان را نسبت به اهداف و كنشكران كليدى كه در مرحله قبل و از طريق

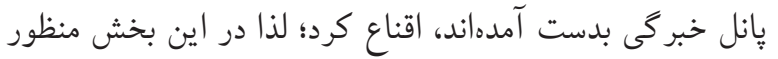
از مصاحبه، كفتخوهاى عميق دو طرفه وانتقادى به منظور جلب

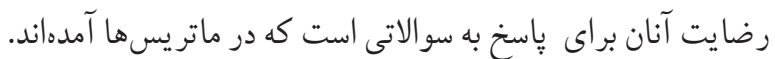
در مورد تعداد خبر گان در زمانى كه محقق به شيوه هدفمند نمونه را انتخاب مى كند در منابع عدد خاصى ذكر نكر ديده اما رهبر

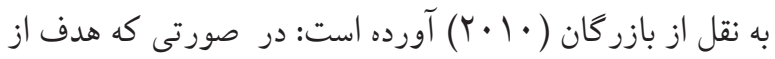
مصاحبه اكتشاف و توصيف عقايد و نكرش هاى مصاحبه شوند كان

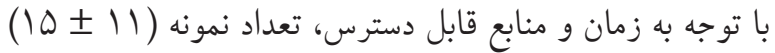
براى انجام مصاحبه كافى خواهد بود(IF) (I). لذا طبق اين ديدكاه

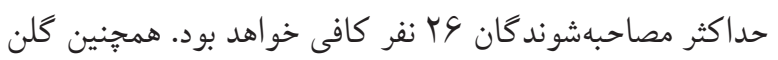

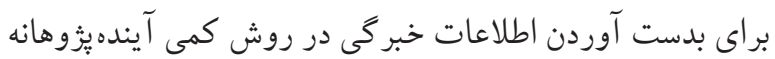

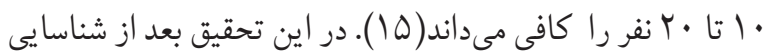
اهداف و كنشگران كليدى نظام سلامت طبق فرايند حاكم بر نرم افزار مكتور ها نفر در مصاحبه و ير كردن ماتريس شركت كردند.
اسطوره / استعاره است كه ابعاد احساسى ناخود آكاه را بيان مىدارد. جالش فراروى آن انجام تحقيقات و حركت در اين لايههاى تحليل و در نتيجه در بر گرفتن شيوههاى مختلف دانستن است انجام اين

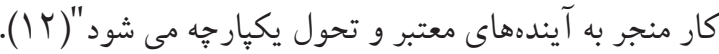

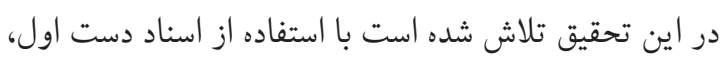
منابع معتبر و همجنين نتايج مطالعات مختلف، اهداف بلند مدت

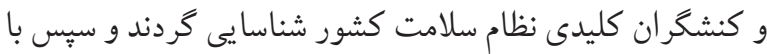
بهرهگيرى از مصاحبه عميق در قالب جلسات ذهنانكيزى و وِانل خبر گى، اهداف نظام سلامت ذيل روش تحليل لايهاى علتها و و دهيه

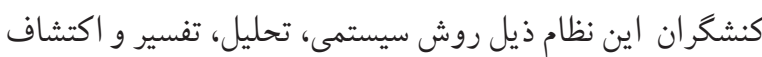

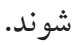

اهداف آينده نظام سلامت ذيل روش تحليل لايهاى علتها شامل زندگى طولانى همراه با سلامتى و كيفيت به عنوان هدف

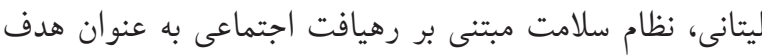

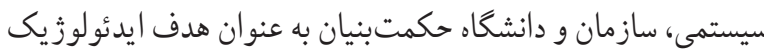
و كفتمانى و در نهايت رفاه و نگًاء جامع به همه ابعاد جسمى، روانى، معنوى و اجتماعى به عنوان هدف استعارهاى و همجنين كنشخران كليدى نظام سلامت ذيل روش سيستمى كه مبتنى بـ بر رهيافت

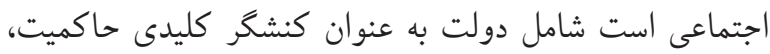
دولت، سازمان برنامه و بودجه، شوراى عالى بيمه، وزارت بهداشت، وزارت رفاه، سازمان نظام يُشكى و مجلس به عنوان كنشكران

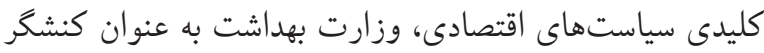
كليدى سياستهاى عمومى نظام سلامت، يزشك خانو اده به عنوان

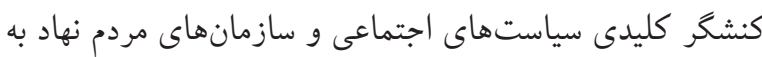
عنوان كنشگران كليدى فرهنگ و ارزشهاى اجتماعى نظام سلامت ستي منتج شده است. در مرحله بعد لازم است اطلاعات بدست آمده از مرحله قبلى را به منظور طبقهبندى بازيخران بر مبناى تاثير گذارى و تاثير يذيرى

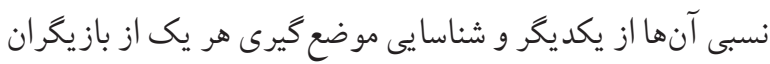

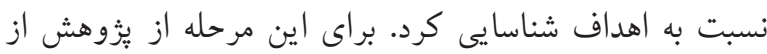
نمونه كيرى هدفمند استفاده شده است. 
(Y) يك كنشكر ممكن است سياستهاى كنشكر دوم را تهديد كند و يا به خطر بيندازد.

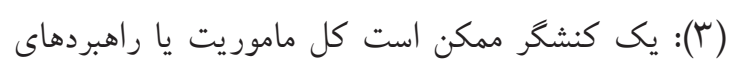
ديخرى را تهديد كند.

(Y) تهديد كند.

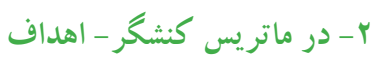
† + اثر كذارى بسيار قوى مثبت(اثر مثبت دارد در تبديل شدن اين هدف به جشمانداز نظام سلامت كشور ) / F- اثر كذارى بسيار قوى منفى(از تبديل شدن اين هدف به جشم انداز نظام سلامت كشور جلو گيرى خواهد كرد) r+ اثر گذارى قوى مثبت (اثر مثبت دارد در تبديل شدن اين

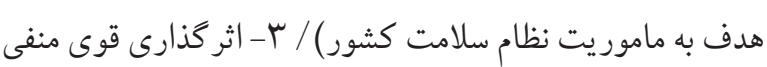
(از تبديل شدن اين هدف به ماموريت نظام سلامت جلو كيرى خواهد كرد) Y + اثر كذارى متوسط مثبت(اثر مثبت دارد در تبديل شدن اين

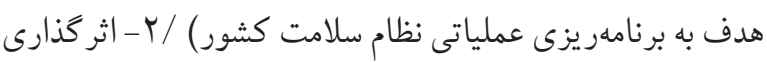
متوسط منفى (از تبديل شدن اين هدف به برنامهر يزى عملياتى نظام سلامت كشور جلو خيرى خواهد كرد) 1 + اثر خذارى معمولى مثبت(اثر مثبت دارد در تبديل شدن اين

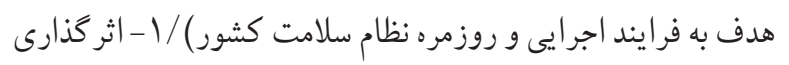

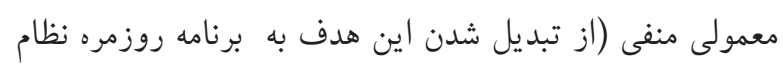

$$
\text { سلامت كشور جلو خيرى خواهد كرد) }
$$

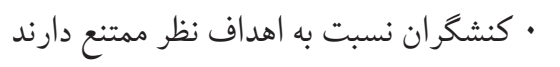

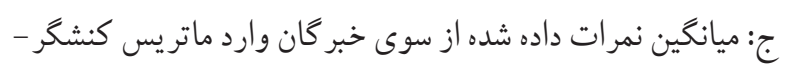

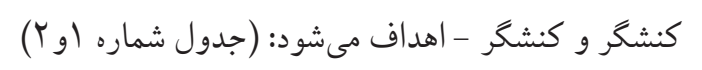

نوع اين تحقيق بر مبناى هدف، كاربردى - توسعهاى است، جرا

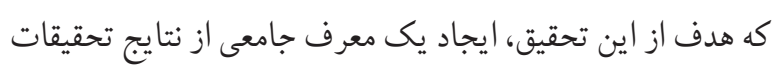

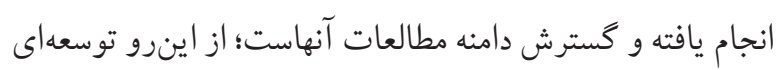
مى باشد؛ از سوى ديكر نتيجه اين تحقيق كمك به تحقق اجتماعى سازى دئه و مردمى كردن نظام سلامت مى كند و براى سازمانهاى ذينفع مهم و

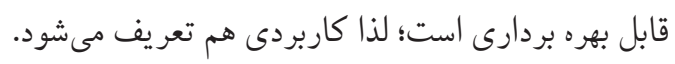
براى تحليل و بررسى ميزان اهميت هر كدام از اهداف و كنشكران

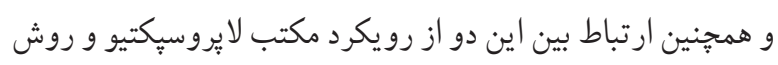
مبتنى بر آن يعنى فرايند حاكم بر نرمافزار مكتور استفاده شده است.

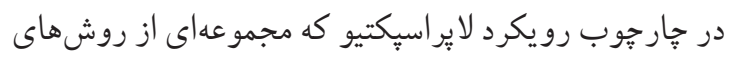
مختلف آيندهيزوهى است، يكى از روشهاي سيستمى و جامع تحليل

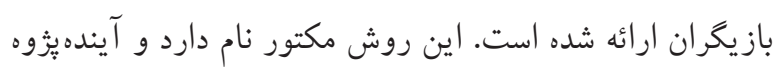

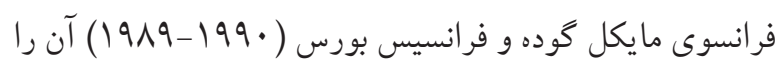
معرفى كردهاند. در اين روش دو هدف اصلى دنبال مى شود. نخست،

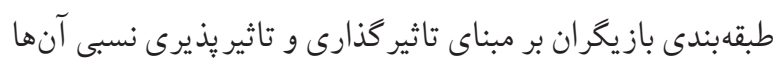

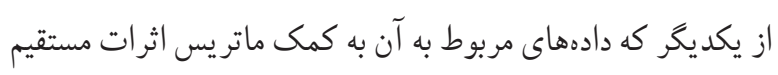

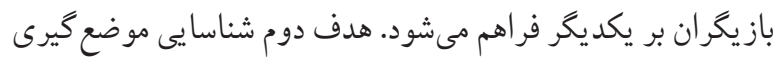

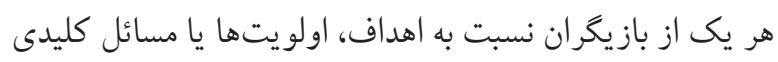
است و براى رسيدن به اين هدف از ماتريس دوبخشى استفاده

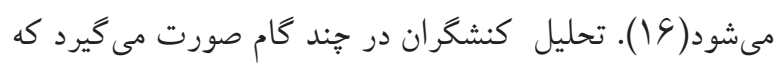
عبارتند از: - مبك الف: ورود كنشكران و اهداف شناسايى شده از قسمت ديدبانى به ماتريس كنشخر - كنشخر و كنشخر - اهداف ب: در ماتريس كنشگر - كنشخر و كنشخر - اهداف از خبر كان خواسته مىشود رابطه بين كنشكران را با توجه به حالتهاي

$$
\begin{aligned}
& \text { زير ارزيابى كنند: } \\
& 1 \text { - در ماتريس كنشخر - كنشخر }
\end{aligned}
$$

( ) (): دو كنشكر اثرى بر هم ندارند يا نفوذ يكى بر ديكرى

$$
\text { بسيار ناجيز است. }
$$

(1): يك كنشخر ممكن است در فعاليتها، برنامهها يا اهداف عملياتى كنشخر دوم تداخل ايجاد كند. 
جدول ا. ميانگين نمرات داده شده از سوى خبر كَان در ماتريس كنشگر - كنشگر

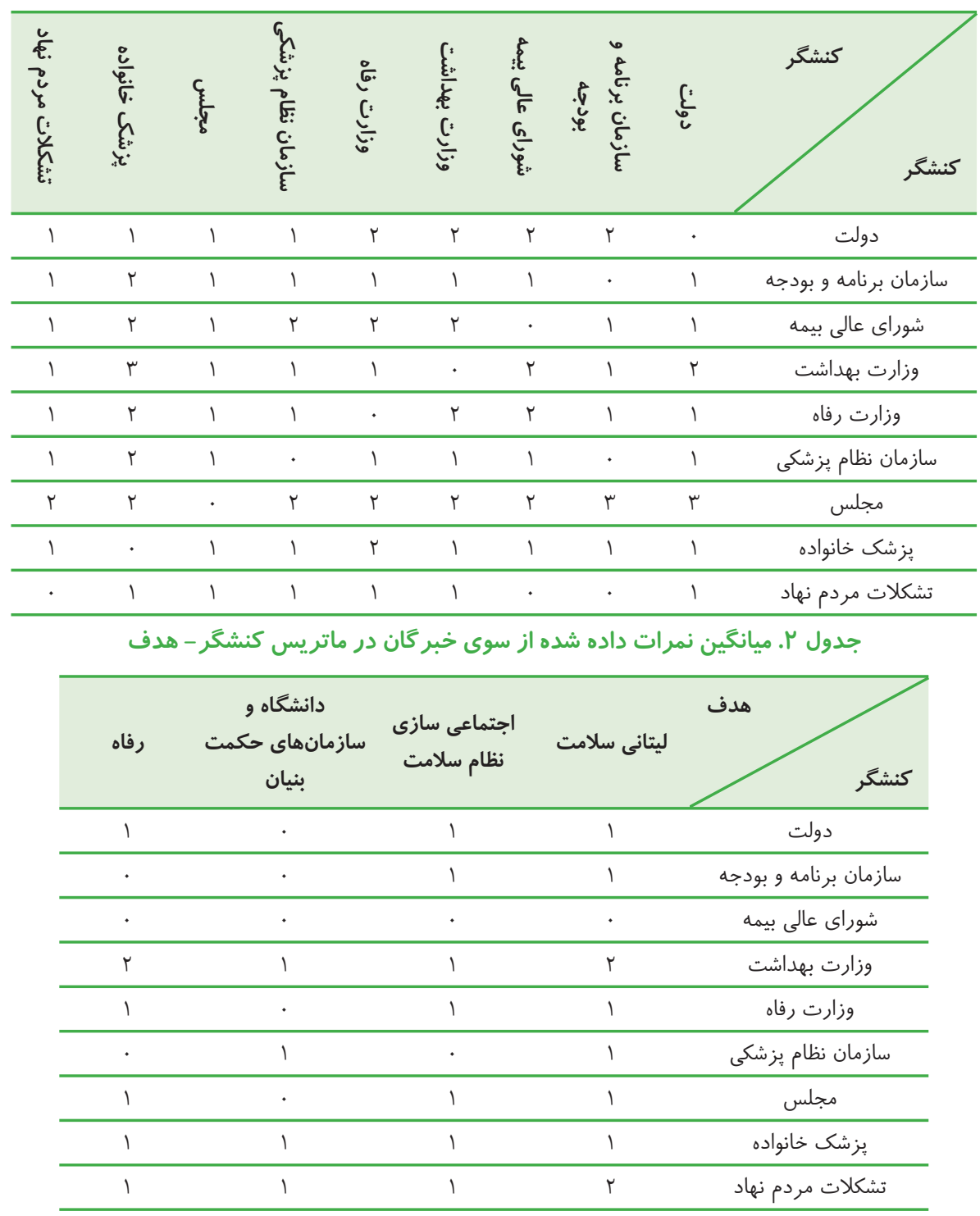

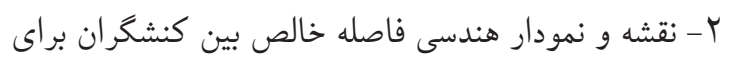

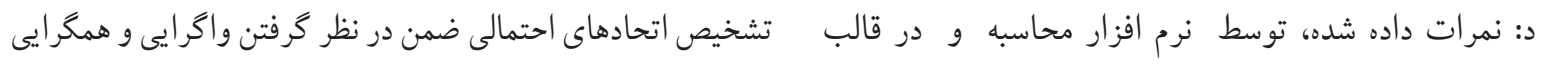

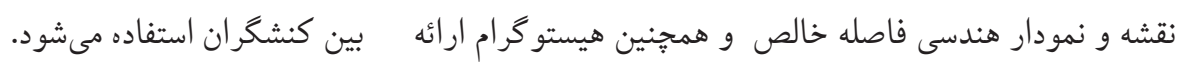

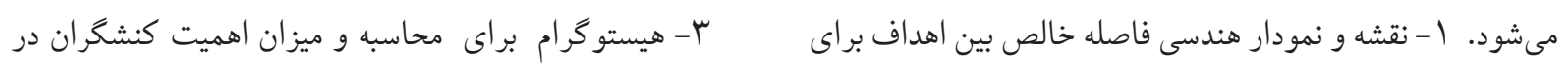

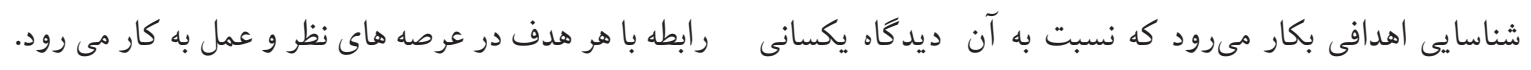

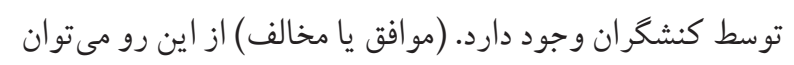

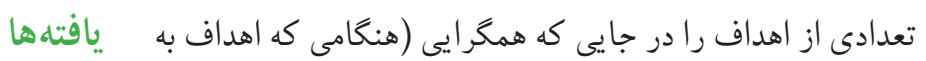

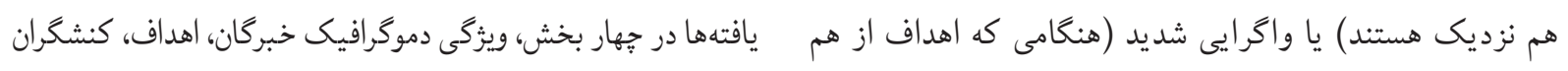

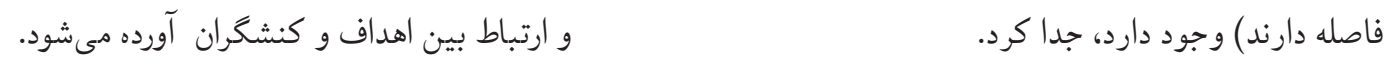




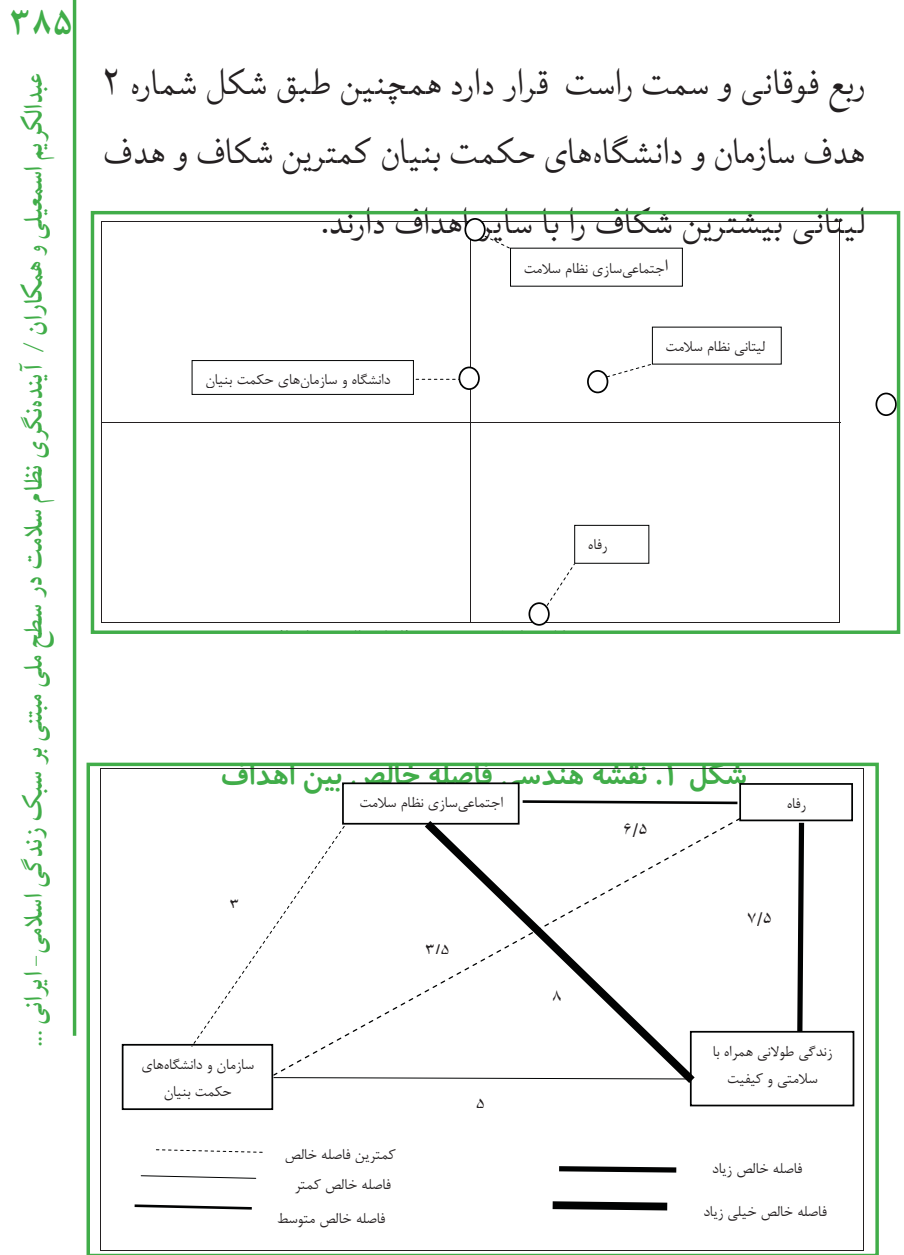

شكل r. نمودارهندسى فاصله خالص بين اهداف

ج: كنشخران

طبق شكل شماره \همه كنشگران به استثناى شوراى عالى بيمه و

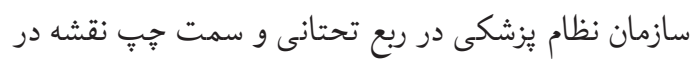

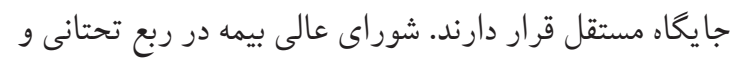

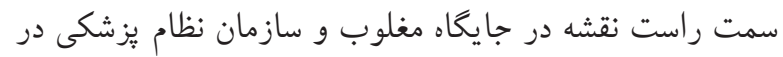

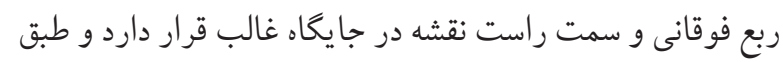

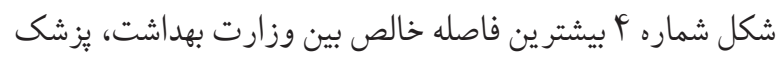

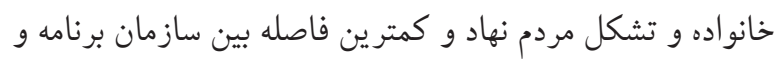
بودجه و سازمان نظام يزشكى با ساير كنشكران وجود دارد.

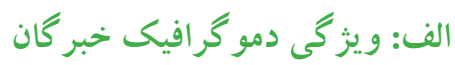
در اين قسمت فراوانى و درصد ويثگى دموكرافيك خبرگان در ها ه بعد سطح تحصيلات، مرتبه علمى، سابقه مديريت در عرصه سلامت، سطح مديريت در عرصه سلامت و سابقه مديريت در حوزه تحقيقات

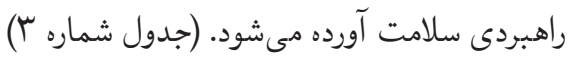
جدول س. فراوانى و درصد ويزَّى دموَّرافيَى خبر گَان

\begin{tabular}{|c|c|c|c|}
\hline درصد & فراوانى & 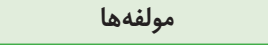 & 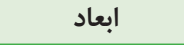 \\
\hline r. & 1. & د دترى عمومى & \multirow{3}{*}{ سطح تحصيلات } \\
\hline r t & $\wedge$ & دكترى تخصصى & \\
\hline rᄉ & $\checkmark$ & دكترى فوق تخصصى & \\
\hline$r$. & $\Delta$ & ام يى اج & \multirow{5}{*}{ مرتبه علمى } \\
\hline$\wedge$ & r & دانشجوى بى اج دى & \\
\hline 19 & r & يَ اج دى & \\
\hline$r$. & $\Delta$ & استاد يار & \\
\hline rs & 9 & استاد & \\
\hline ir & r & ه تا • ا سال & \multirow{5}{*}{ سابقه مديريت در سلامت } \\
\hline rs & 9 & 11 ا تا ها سال & \\
\hline$r$. & $\Delta$ & عا تا ·r سال & \\
\hline 19 & r & ا r تا ro سال & \\
\hline 10 & r & צr تا •r سال & \\
\hline re & $\wedge$ & مدير در سطح دانشگاه & \multirow{5}{*}{ سطح مديريت در سلامت } \\
\hline rᄉ & $\checkmark$ & معاون دانشگاه & \\
\hline ir & r & رئيس دانشكاه & \\
\hline$r$. & $\Delta$ & مدير در سطح وزارتخانه & \\
\hline$\wedge$ & r & معاون وزير & \\
\hline rs & 9 & ا تا ه سال & \multirow{6}{*}{ در حابقه مديريت } \\
\hline$r$. & $\Delta$ & צ تا · ا سال & \\
\hline$r F$ & 4 & 11 تا هاسال & \\
\hline ir & r & 1 1 تا · r سال & \\
\hline r & 1 & ا آتا & \\
\hline r & 1 & عץ تا •r سال & \\
\hline
\end{tabular}

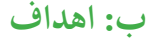
طبق شكل شماره ا هدف رفاه در ربع تحتانى و سمت جٍٍ نقشه در جايخاه مستقل ، اهداف ليتانى و اجتماعى سازى در ربع فوقانى

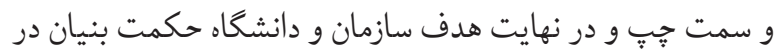



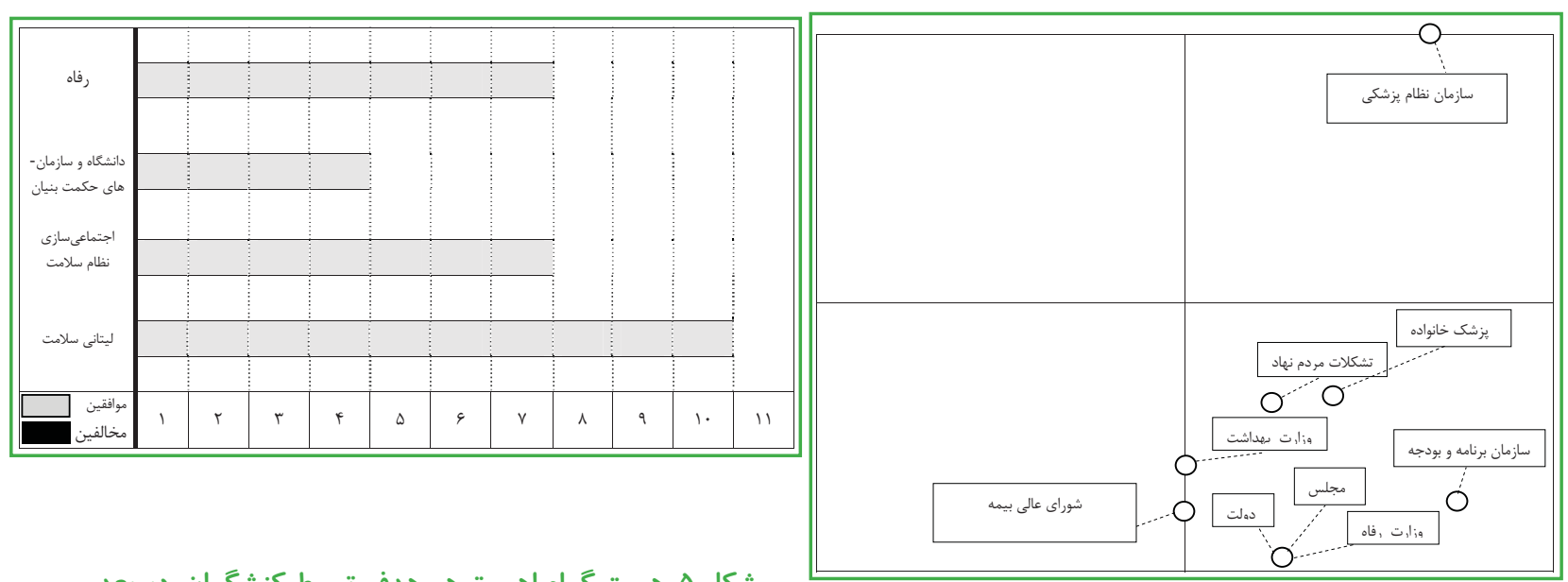

شكل ه. هيستو گرام اهميت هر هدف توسط كنشگران در بعد

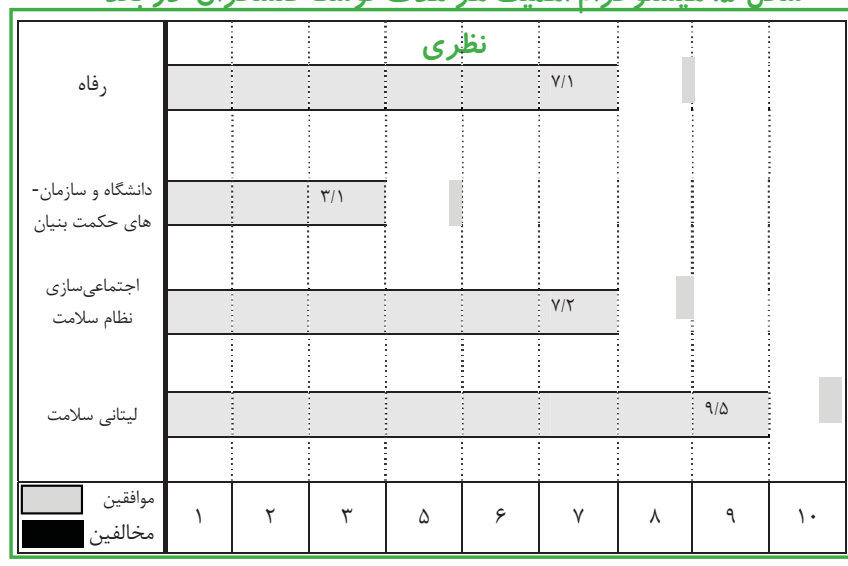

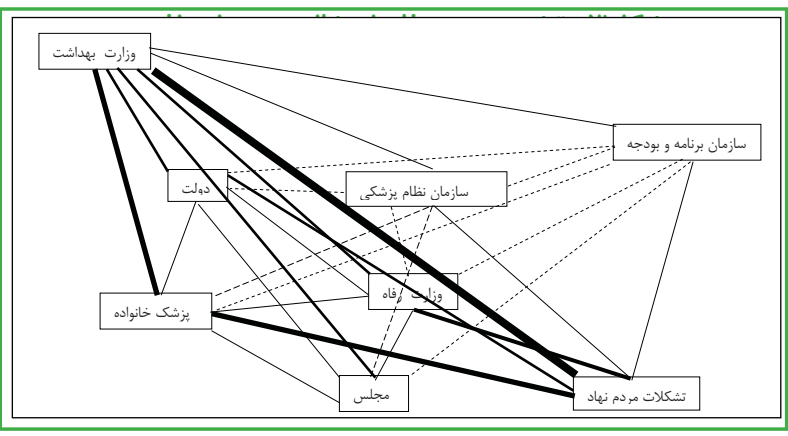

شكل צ: هيستو کرام اهميت هر هدف توسط كنشكران در بعد شكل عا. نقشه هندسى فاصله خالص بين اهداف عملى د: رابطه بين اهداف و كنشخران طبق اشكال شماره ه و 9 هدف رفاه از ديدگاه كنشگران داراى بحث نظام سلامت كشور براى ساخت مطلوب آن داراى سه كنشكر كليدى

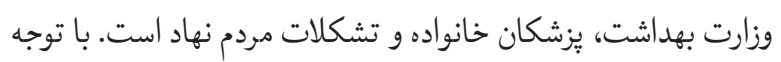
به ارزش گرا بودن اين تحقيق و مشابهت زيادى كه به مدل دانشگاه

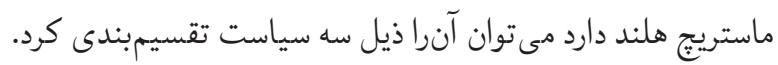
اين مدل تحت عنوان مراقبت سلامت ارزش يايه (VHC)' معرفى مانى

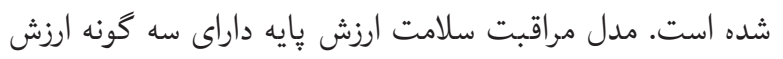

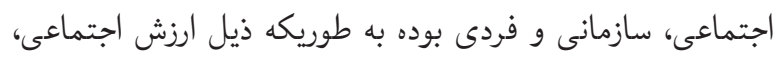
اهميت متوسط و در هنخام عمل با افزايش اهميت و هدف سازمان

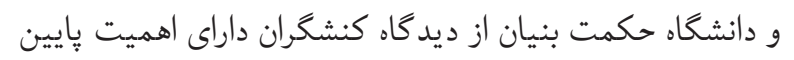
و در هنكام عمل با كاهش اهميت كمتر روبرو مىشود، همجنين

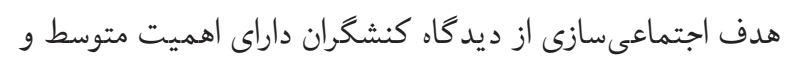

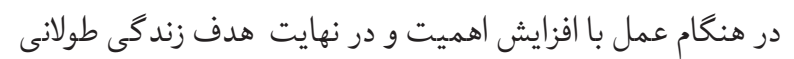

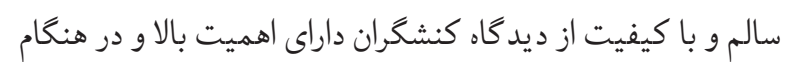
عمل با كاهش اهميت روبرو مىشود.

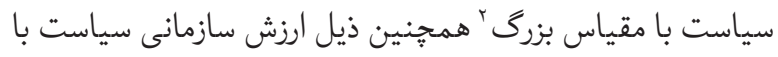


آموزش، يُووهش، نوآورى و كار آفرينى و در نهايت يذيرش و

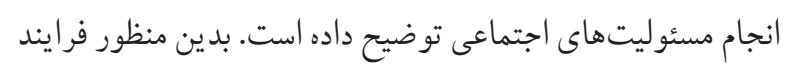

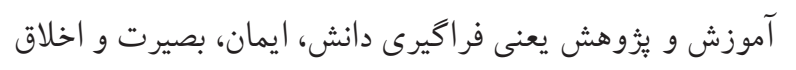

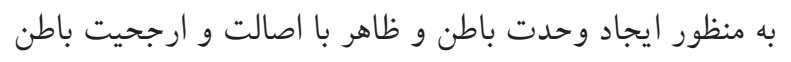

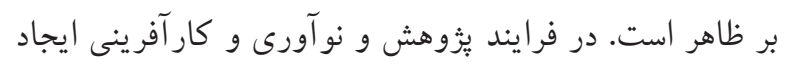

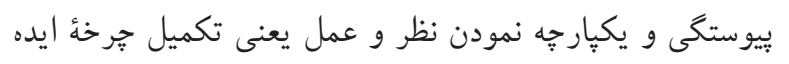
تا محصول و كسب ثروت مورد تاكيد بوده و در نهايت در فرايند

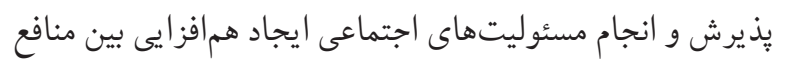
فردى و مصالح جمعى با ترجيح جمع بر فرد مورد تاكيد است (11).

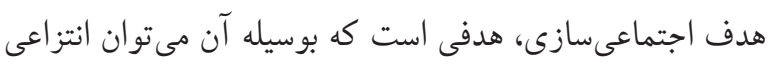

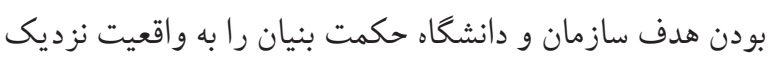

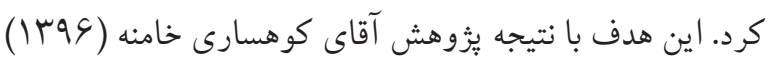

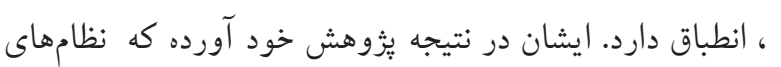

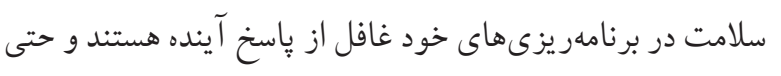

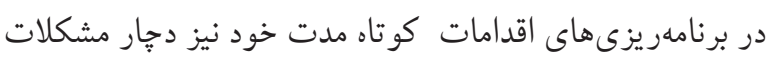

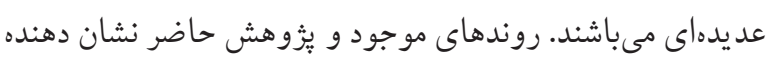

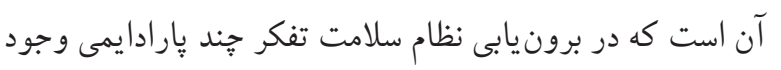

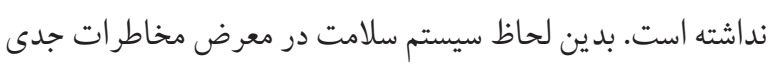

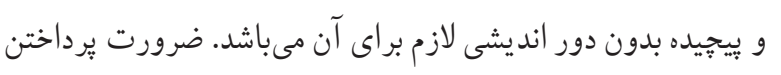

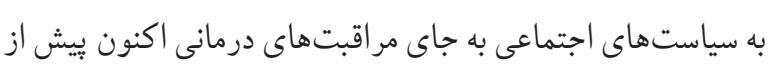

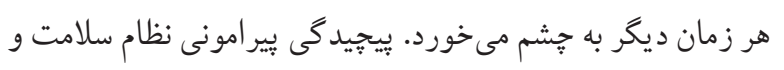

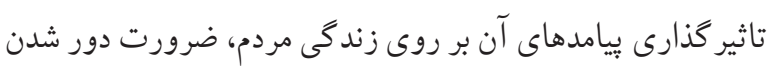

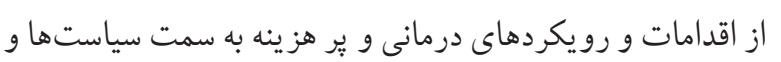
اقدامات اجتماعى با همكارى همه بخشها را نشان مى إدهد (19).

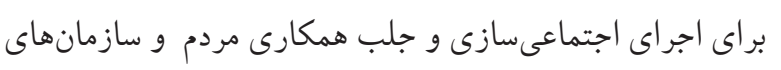
مردم نهاد نياز مبرمى به استعارهسازى در نظام سلامت وجود د دارد.

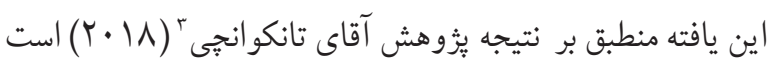

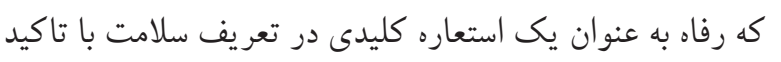
بر تعيين كنندهاى اجتماعى سلامت و با جهت گيرى مطالعات بين يار ادايمى معرفى شده است( • (Y).

3. Tankwanchi
مقياس متوسط' و در نهايت ذيل ارزش فردى سياست با مقياس

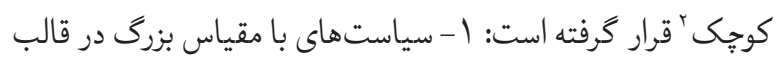

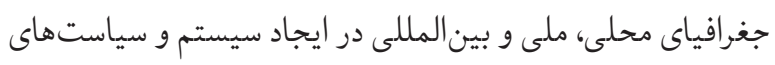

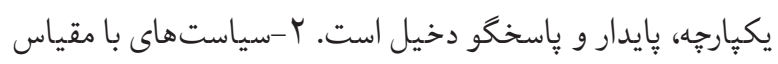

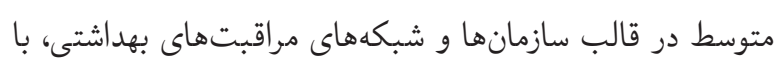
محوريت ايجاد سازمانهاى كارآمد و شبكههاى يكيارجه در بخش ونش بهداشت و درمان و ساير بخشها، كه ارائه دهنده خدمات و محصولات مؤثر هستند. ب-سياستهاى با مقياس كوجى متمركز بر تعامل بين ارائه دهندگان خدمات بالقوه سلامت و گيرند مان اين نوع از

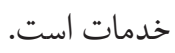
با توجه به مدل دانشكاه ماستر يج هلند و اطلاعات بدست آمده

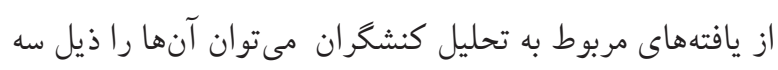
نظام تحليل كرد. الف - نظام عمومى سلامت كه سياست با مقياس

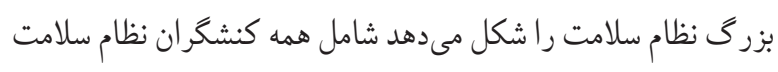

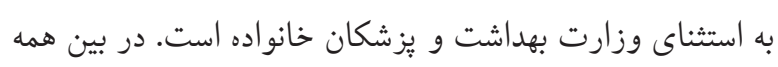
كنشگران اين نظام سازمانهاى مردم نهاد جايكاه محورى دارد. اين

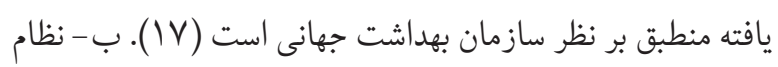

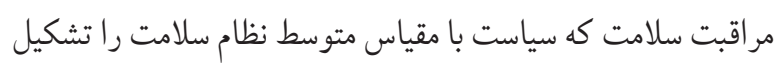

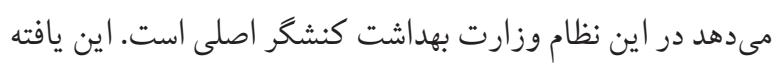
منطبق بر برنامه ششم توسعه كشور كه در آن وزارت بهداشت در آنس عرصه سازمانى نقش توليت نظام سلامت را به عهده دارد. ج - نظام ارجاع كه در آن يزشك خانو اده نقش كليدى دارد. اين يافته منطبق

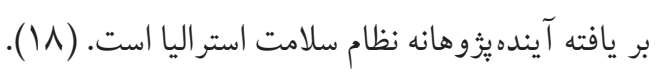
در مورد اهداف بلند مدتى كه در اين تحقيق به عنوان آينده

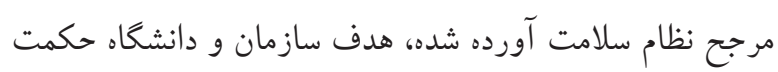

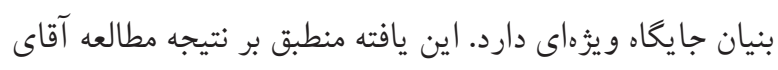

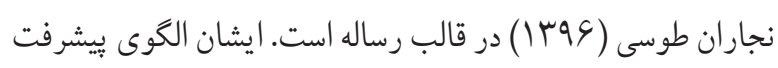
دانشخاه تراز انقلاب اسلامى كه مبتنى بر انديشهائ امامين انقلاب اسلامى باشد را در طر احى حكمت بنيان بودن بيشرفت دانشعاهها

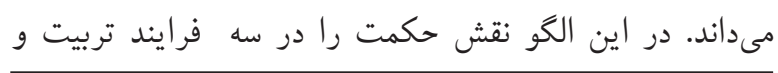


همراه باكيفيت خواهد بود. نظام سلامت هر كشورى جيزى جداى از ايدئولوزى حاكم بر جامعه و سبك زند كَى مردم آنها نيست.

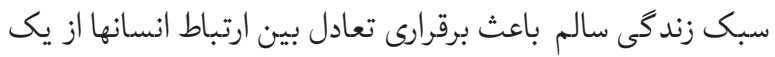

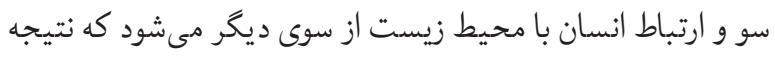

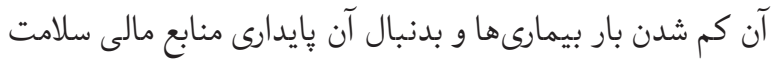
خواهد بود. پايدارى منابع مالى فرصت برابر را در ارائه خدمات ايجاد باد باد بادي مى كند. ساختار فعلى حاكم بر نظام سلامت به دليل رويكرد بيمار

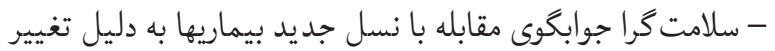
سبك زند گى نيست. لذا يِيشنهاد مى شود وزارت بهداشت، درمان

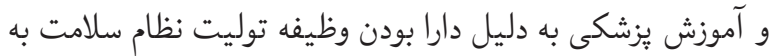

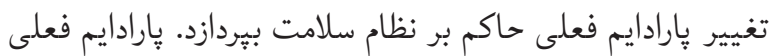

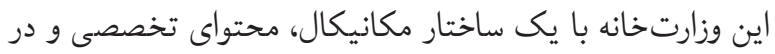
زمينه بيمار- بيمارستان محور قادر نخواهد بود از توليت خود براى تشريك مساعى با ساير سازمانها بهره ببرد. اين وزارت خانه مى تواند با تمركز و برنامهريزى با رويكرد تندرستى محورى (سالم- سلامت گرا)

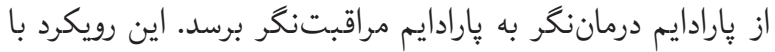

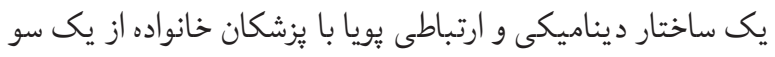

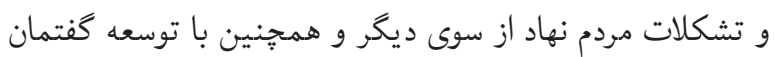
حكمت بنيان و توجه به مطالعات ميانرشتهاى و در يك زمينه

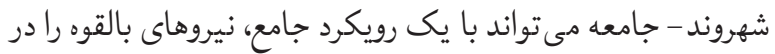

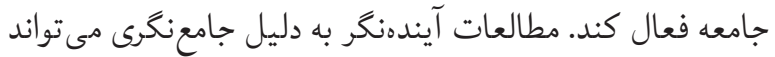
از آفت بخشى نكرى بيشخيرى كند. تقدير و تشكر تر بحك اين مطالعه بخشى از رساله دكترى آيندهيزوهى تحت عنوان طراحى

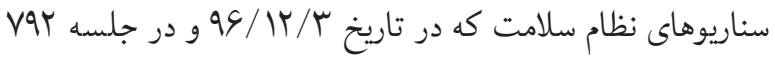
شوراى دانشگاه عالى دفاع ملى به تصويب رسيده است. از آنجاييكه

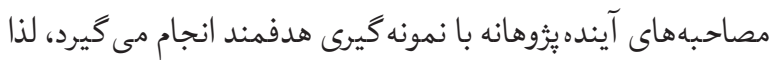

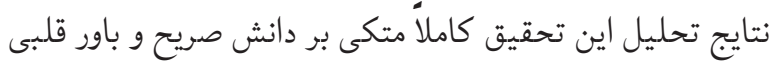
و شهود خبركانى است كه هم بر شيوه تحقيق در عرصه سلامت و

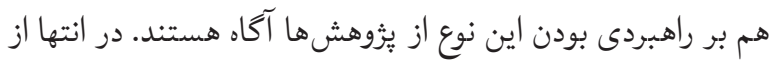

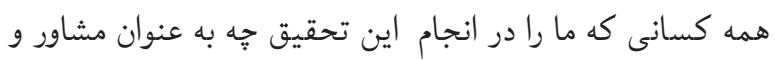

براى اجتماعى سازى تنها جلب همكارى مردم و سازمانهاى مردم نهاد كافى نيست بلكه همه سازمانها و نهادهاى حكومتى متناسب با بال

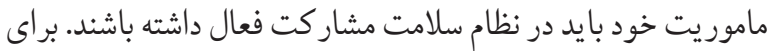
اين منظور ترويج هدف زندگى طولانى سالم و با كيفيت مد نظر بوده.

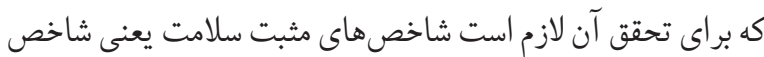
اميد به زندگى و اميد به زندگى سالم به عنوان ليتانى يا همان واقعيت بيرونى نظام سلامت كشور در نظر گرفته شود. اين يافته منطبق بر

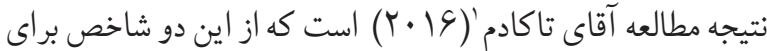
تعيين وضعيت سلامت جامعه و برنامهريزى جهت بالا بردن كيفيت

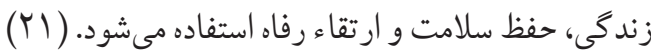
وزارت بهداشت به عنوان متولى مىتواند با استفاده از جهار هدف رفاه، سازمان و دانشكاه حكمت بنيان، اجتماعىسازى نظام سلامت و زندكى طولانى سالم و با كيفيت به گونهاى سياست گذارى كند

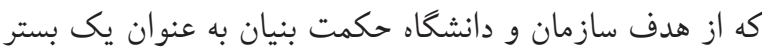

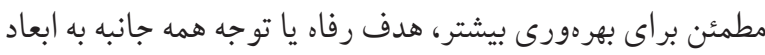

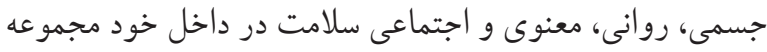
سازمانى و دانشخاهى در ابعاد سياست گذارى، آموزش و تحقيقات

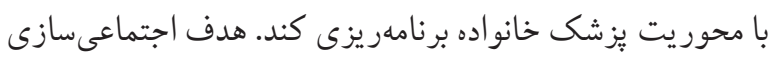

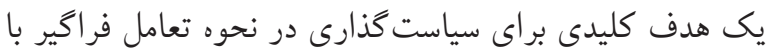
ساير وزارتخانها و سازمانهاى مردم نهاد است. و در نهايت هدف

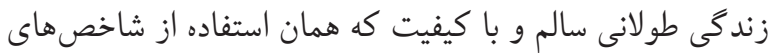

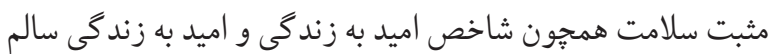
است به عنوان يك خط مشى براى يكيارجهازسى سياست ارتقاء سلامت با سياستهاى بيشخيرى، درمان و نوتوانى استفاده شود. نتيجان كيرى فلسفه وجودى نظام سلامت هر كشورى در جهت گيرى تندرستى

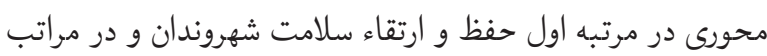

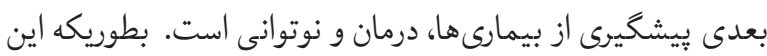
شهروندان بتوانند در كنار خدمات عادلانه به رفاه جسمى، روانى و اجتماعى و معنوى دست ييدا كنند. ما حصل اين رفاه طول عمر بهر بهر 
جه به عنوان مصاحبه شونده يارى كردند تشكر و قدردانى مى گردد. References

1. Hatami, H, Razavi, SM, Iftikhar Ardabili, H, Majlisi, F, Comprehensive book of public health, 3rd ed, Tehran, Arjmand Publications, 2014.

2. Policy Council of the Ministry of Health, Achievement and Challenges and Horizontal front side Republic of Iran Health system, 1th ed, Tehran: Ministry of Health and Medical Education Publications, 2011

2. Dalvandi, A, Madah, SSB, Khankeh, HR, Bahrami, F, Parvaneh, S, Hesamzadeh, A, Dalundi, N, Kiani, T, Explaining a Health-Based Lifestyle Based on Islamic Culture, Journal of Qualitative Research in Health Sciences, 2012; 1(4): 43332

3. Tabatabai, The necessity of future research in the medical education and health system of the country, Journal of the Center for the Study and Development of Medical Education, 2016; 12(2): 433-435.

4- Ledford CJ, Cafferty LA, Russell TC. The influence of health literacy and patient activation on patient information seeking and sharing. Journal of health communication. 2015;20(sup2):77-82. https://doi.org/10.1080/10810730.2015.1066466 PMid:26513034

5. Goharinezhad S, Maleki M, Baradaran HR, Ravaghi H. A qualitative study of the current situation of elderly care in Iran: what can we do for the future? Global health action. 2016;9:32156. https://doi .org/10.3402/gha.v9.32156 PMid:27876456 PMCid:PMC5120385

6. Wasi, P. Triangle That Moves the Mountain and Health Systems Reform Movement in Thailand, Human Resources for Health Development Journal (HRDJ), 2000; 4(2), available from: http://www.hsro.or.th

7. van der Laan L. Health care foresight: identifying megatrends, convergence and scenarios of ways in which the future can be imagined. 2017.

8. O'Connor CA, Dyson J, Cowdell F, Watson R. Do universal school-based mental health promotion programmes improve the mental health and emotional wellbeing of young people? A literature review. Journal of clinical nursing. 2018;27(3-4):e412-e26. https://doi.org/10.1111/jocn.14078

9. WHO, monitoring the building blockes of health systemesa handbook of indicators and their measurement strategies, 2010, https://www.who.int/sdhconference/resources/ ConceptualframeworkforactiononSDH_eng.pdf

10. Sardar, Z, Islam, Postmodernism and Other Futures, 2003, 1rd Ed, Pluto Press, available at: www.plutobooks.com

11. Holov S. Futurology of accounting. Bulletin of the National university" Lviv Polytechnic" Management and entrepreneurship in Ukraine: stages of formation and development problems. 2014;794:153-7

12. Riedy C. An integral extension of causal layered analysis. Futures. 2008;40(2):150-9. https://doi.org/10.1016/j.futures.2007.11.009

13. - Young SM. Field research methods in management accounting. Accounting horizons. 1999;13(1):76. https://doi.org/10.2308/acch.1999.13.1.76

14. Rahbar F, Asl S-e, Ali A, Shahhosseini MA, Niazi E. Designing a Model for Scenarios Based on Identifying Key Factors and Analyzing the Key Actors' Interactions. Management Researches. 2018;11(39):61-90.

15. Allen TD, Eby LT, O'Brien KE, Lentz E. The state of mentoring research: A qualitative review of current research methods and future research implications. Journal of Vocational Behavior. 2008;73(3):343-57. https://doi.org/10.1016/j.jvb.2007.08.004

16. Lamé $G$, Jouini $O$, Stal-Le Cardinal J. Methods and contexts: Challenges of planning with scenarios in a hospital's division. Futures. 2019;105:78-90. https://doi.org/10.1016/j.futures.2018.09.005

17. WHO. system thinking for Health Systems Strengthening, 2009, available at: http://www.who.int/alliance-hpsr

18. Inayatullah. Health futures for Queensland, Australia, 2000, available at: www.metafuture.org.

19. Kouhsari Khameneh A, Zanganeh Baygi M, Seyadin SH, Rajabi Fard Mazrae No F. Adaptation Of Goals And Organizational Structure In Iran's Primary Healthcare System, A Systematic Review. Payavard Salamat. 2016;9(5):446-58.

20. Tankwanchi ABS. Oppression, liberation, wellbeing, and ecology: organizing metaphors for understanding health workforce migration and other social determinants of health. Globalization and health. 2018;14(1):81. https://doi.org/10.1186/s12992-018-0397-y PMid:30092811 PMCid:PMC6085714

21. Tokudome S, Hashimoto S, Igata A. Life expectancy and healthy life expectancy of Japan: the fastest graying society in the world. BMC research notes. 2016;9(1):482. https://doi.org/10.1186/s13104-016-2281-2 PMid:27793196 PMCid:PMC5084424 